\title{
The effects of various mouthwashes on the oral environment change for oral health care.
}

\author{
Ah-Reum Shin, Seoul-Hee Nam* \\ Department of Dental Hygiene, College of Health Sciences, Kangwon National University, Samcheok-si, Republic of \\ Korea
}

\begin{abstract}
The purpose of this study was to emphasize the necessity of gargling for a pleasant oral environment, to examine the changes in the oral environment through the saliva before and after the use of optimal mouthwashes for the most effective and continuous oral care among various mouthwashes, and to improve the oral environment. This study was conducted on 20 female students at a university located in Gangwon Province who did not have any special medication history within the last 6 months and did not smoke. Group $1(n=5)$ gargled with $0.2 \%$ chlorhexidine gluconate $(\mathrm{CHX})$, group $2(\mathrm{n}=5)$ with $7.5 \%$ Povidone Iodine (PVI), group 3 (n=5) with sodium bicarbonate-normal saline, and group $4(n=5)$, the control group, with sterile distilled water. After collecting $10 \mathrm{ml}$ saliva from each group, $15 \mathrm{ml}$ of each solution was used for $1 \mathrm{~min}$, and then $10 \mathrm{ml}$ saliva was collected. The results showed that there was a significant difference in $\mathbf{p H}$ in the $\mathrm{CHX}$ and PVI groups $(\mathbf{p}<0.05)$, and there was a significant decrease in the O'Leary index in the CHX, PVI, and sodium bicarbonate-normal saline groups $(p<0.05)$. In addition, there was a statistically significant difference in Streptococcus mutans $(S$. mutans) $(P<0.05)$ in the order of the PVI and CHX groups $(\mathbf{p}<\mathbf{0 . 0 5})$. In terms of the Snyder test, all the groups showed a statistically significant difference $(p<0.05)$. Therefore, it was confirmed that mouthwashes improve the oral environment, and $7.5 \%$ PVI was the most effective mouthwash, followed by $0.2 \%$ CHX.
\end{abstract}

Keywords: Mouthwash, Chlorhexidine gluconate (CHX), Povidone iodine (PVI), Sodium bicarbonate-normal saline, Changes in the oral environment.

Accepted on March 27, 2018

\section{Introduction}

Dental caries and periodontal disease are the two major chronic oral diseases, which are multifactorial disorders that cannot be reversed to the original oral state before the onset of the disease once it occurs [1]. It is already well known that these two major oral diseases are caused by dental plaque [2]. Dental plaque causes dental caries by demineralizing the minerals in the tooth structure, and the periodontal-disease-related bacteria in the dental plaque produce harmful toxins in the periodontal tissue, which is a direct cause of periodontal disease [3]. Therefore, it is important to have a healthy oral environment through personal oral care (i.e., dental plaque management) because the proper recognition and practice of oral health care is important, and oral diseases can be prevented [4].

Among the various kinds of oral care aids for dental management, the use of mouthwash is increasing in South Korea, and many studies have been conducted for the effective removal of bad breath as well as the prevention of the two aforementioned major oral diseases [5]. The study conducted by Jung [3] also showed that the use of gargle solution is gradually increasing in the order of mouthwashes, interdental toothbrushes, and dental flosses, indicating that the consumption of mouthwash is increasing as the interest in oral health increases with the improved standard of living of the people [6]. As another reason, the use of mouthwash seems to be increasing because it reduces the number of pathogenic bacteria in the mouth, keeps the mouth soft, and conveniently removes the foreign matters in the mouth [7]. There are various kinds of mouthwashes to date [8], and of those, normal saline, tantum, Chlorhexidine gluconate (CHX), Povidone Iodine (PVI), and nystatin solution are mainly used in clinical practice [9]. CHX, the most effective mouthwash, is known to have a selective effect on Streptococcus mutans (S. mutans), a major causative organism of dental caries [10]. In addition, as the said mouthwash has an excellent effect in terms of inhibiting dental plaque formation as well as an antibacterial effect, it is commercially available in various forms, such as detergents with various concentrations, gels, injections, toothpaste, and gums [11]. It has side effects, however, such as an unpleasant taste, a change in taste in the case of long-term use, and tooth discoloration [12]. PVI, on the other hand, causes relatively low irritation to the oral mucosa and has a strong sterilizing effect. It is a mixture of polyvinyl pyridine and iodine, reducing iodine-related irritation, pigmentation, and allergic reactions and exhibiting the antibacterial action of iodine 
simultaneously [13]. As a topical disinfectant, it is used prophylactically in the oral mucosa and is widely used as a sterilizer and mouthwash due to its oral antibiotic effect [14]. It has a poor taste and flavor, however, and can interfere with the regeneration of epidermal cells and granulation tissues [15]. CHX and PVI mouthwashes have been studied continuously, and it has been reported that the oral administration of $\mathrm{CHX}$ and PVI for 1 min can effectively reduce the number of oral bacteria [16]. The effect of sodium bicarbonate-normal saline, which has emerged of late, has not yet been proven, but it is often recommended in clinical practice because it is less costly and gives less discomfort to the patients [17]. It has a disadvantage, however, in that it cannot be used alone, like other mouthwashes, because it has not demonstrated any definitive effect [18]

Appropriate mouthwashes should not cause an injury physically or chemically, should not cause decalcification, and must be non-toxic. Moreover, it should not interfere with the activity of the saliva, does not have a bad odor or taste, has an ability to physically or chemically remove the eliminated matters, should create a humid environment, and has a lubrication effect [19]. Mouthwash is the simplest, but when used periodically, it is effective in terms of the functional aspect and should not cause discomfort or injury in the mouth [20]. Despite the large number of previous studies on mouthwashes used for oral care, there is insufficient evidence to support the clinical efficacy of mouthwashes.

Therefore, this study aimed to emphasize the necessity of gargling for a pleasant oral environment, to examine the changes in the oral environment through the saliva before and after the use of optimal mouthwashes for most effective and continuous oral care among the various mouthwashes, and to improve the oral environment.

\section{Materials and Methods}

\section{Study subjects}

This study was conducted on 20 female students at a university located in Gangwon Province, who did not have any special medication history within the last 6 months, and did not smoke. Among the total of 20 subjects, 5 gargled with $\mathrm{CHX}, 5$ with PVI, 5 with sodium bicarbonate-normal saline, and 5 with sterile distilled water (control group). The experiment was conducted after providing explanations on the study purpose and method to the subjects, and after obtaining their consent.

\section{Experimental treatment}

Group 1 gargled with $15 \mathrm{ml}$ of $0.2 \% \mathrm{CHX}$ (hexamethine, Bukwang Pharm Co., Ltd., Seoul, South Korea), and Group 2 with $15 \mathrm{ml}$ of $7.5 \%$ PVI (povidone iodine solution $7.5 \%$, Firson Co., Ltd., Cheonan, South Korea), after the solutions were diluted 15-fold according to the instructions of the manufacturer. Group 3 gargled with $15 \mathrm{ml}$ sodium bicarbonatenormal saline after adding $20 \mathrm{~g}$ sodium bicarbonate to $1 \mathrm{~L}$ normal saline according to the method suggested in the study of Kim et al. [21]. Group 4 gargled with $15 \mathrm{ml}$ distilled water as the control group. Before the experiment, $10 \mathrm{ml}$ saliva at the stabilized state was collected, and after gargling with the mouthwash of each group for $1 \mathrm{~min}, 10 \mathrm{ml}$ saliva was again collected.

\section{pH measurement}

The $\mathrm{pH}$ of the $10 \mathrm{ml}$ saliva at the stabilized state before and after gargling with the mouthwash of each group was measured using a pH meter (Horiba Laqua F-71, pH/orp meter, Kyoto, Japan). After measuring the $\mathrm{pH}$, the glass electrode was washed with sterile distilled water each time to measure the $\mathrm{pH}$ of the saliva of all the groups.

\section{Halitosis check}

The Oral Gas (OG) and Exhaled Gas (EG) were measured with an oral gas detector (BB Checker ${ }^{\circledR}$ mBA-21, Plustech, Seoul, South Korea) before and after gargling. For OG measurement, the subjects were instructed to bite the mouthpiece in their mouth once the $180 \mathrm{~s}$ countdown started, to measure the OG for $15 \mathrm{~s}$. For EG measurement, on the other hand, the subjects were instructed to bite the mouthpiece in their mouth once the $30 \mathrm{~s}$ countdown started, and to take a long breath for $15 \mathrm{~s}$ for the measurement of the EG. The measurements in all the groups were conducted in the same manner, and the concentration of the sulfur compounds was quantified and averaged. The evaluation criteria are shown in Table 1.

\section{O'Leary index}

To measure the location and amount of dental plaque efficiently, garnet disclosing solution (Dharma Research Inc., Miami, USA) is applied to the surface of the teeth to be examined to measure the presence of dental plaque. All the teeth in the oral cavity are divided into four areas (mesial surface, distal surface, buccal/labial surface, and lingual surface), and the index is calculated as the percentage of dental plaque present in the gingival margin of each area.

\section{S. mutans test}

S. mutans was cultured at $37^{\circ} \mathrm{C}$ for $24 \mathrm{~h}$ after applying $1 \mathrm{ml}$ saliva to the Brain Heart Infusion (BHI, Sigma-Aldrich, St. Louis, MO, USA) agar medium before and after gargling for each group, and then the amount of $S$. mutans was quantified. The Colony-Forming Units (CFU) were measured and quantified.

\section{Snyder test}

To evaluate the caries activity, Snyder (Snyder Test, Difco Detroit, MI, USA) agar medium was prepared, and after $0.2 \mathrm{ml}$ saliva before and after gargling was injected to the $7 \mathrm{ml}$ medium, the mixture was mixed well and cultured at $37^{\circ} \mathrm{C}$ for $24 \mathrm{~h}$. After $24 \mathrm{~h}$, the color change of the cultured medium was observed for evaluation. The evaluation criteria are shown in Table 2. 


\section{Data analysis}

The data obtained from each experiment were analysed with the SPSS (SPSS 19.0, SPSS Inc., Chicago, USA) program. To compare the oral environments before and after gargling with the various mouthwashes, the paired t-test was performed. Additionally, to compare the effects of the various mouthwashes among the groups, one-way ANOVA was performed, and Tukey HSD was used for the post hoc test. The statistical significance level was set to 0.05 .

\section{Results}

\section{Change in pH}

Table 3 shows the $\mathrm{pH}$ values for the difference between before and after gargling. In terms of the change that occurred after gargling with $\mathrm{CHX}$ and $\mathrm{PVI}$, the $\mathrm{pH}$ value increased, and there was a statistically significant difference in both groups $(\mathrm{P}<0.05)$. In the sodium bicarbonate-normal saline group, however, there was a slight increase, but it was not statistically significant $(\mathrm{P}>0.05)$. The $\mathrm{pH}$ decreased in the distilled water group (control group), but it was not statistically significant $(\mathrm{P}>0.05)$. The comparison of all the groups showed a definite increase in $\mathrm{pH}$ in the CHX and PVI groups $(\mathrm{P}<0.05)$.

\section{Measurement of $O G$ and $E G$ via Halitosis check}

In terms of $O G$ and EG, there was no statistically significant difference before and after gargling in all the groups (CHX, PVI, sodium bicarbonate-normal saline, and distilled water groups) $(\mathrm{P}>0.05)$ (Table 3$)$.

\section{Comparison of $O$ 'Leary index}

In terms of the O'Leary index, there was a statistically significant difference before and after gargling in the CHX, PVI, and sodium bicarbonate-normal saline groups, but not in the distilled water group $(\mathrm{P}<0.05)$. The comparison of all the groups showed a distinct effect in all the groups except for the distilled water group $(\mathrm{P}<0.05)$.

\section{Change in the CFU of S. mutans}

Figure 1 shows the difference in CFU of $S$. mutans. There was a statistically significant difference before and after gargling with CHX and PVI $(\mathrm{P}<0.05)$. The CFU of $S$. mutans in the sodium bicarbonate-normal saline group decreased, but it was not statistically significant $(\mathrm{P}>0.05)$. There was no great change in the CFU of $S$. mutans in the distilled water group, which was not statistically significant $(\mathrm{P}>0.05)$ (Table 3$)$. The comparison of all the groups showed the largest decrease in PVI, followed by CHX.

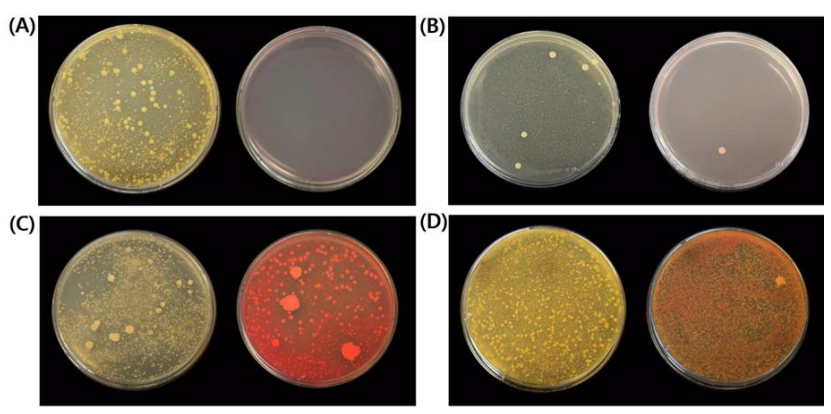

Figure 1. Comparison of the CFU of $S$. mutans according to various mouthwashes: (A) CHX; (B) PVI; (C) sodium bicarbonate-normal saline; and $(D)$ distilled water.

\section{Snyder test}

In all the mouthwashes, there was a color change (Figure 2), indicating inactivity in all the groups (CHX, PVI, sodium bicarbonate-normal saline, and distilled water groups), although there was a difference in the degree $(\mathrm{P}>0.05)$ (Table $3)$.
(A)

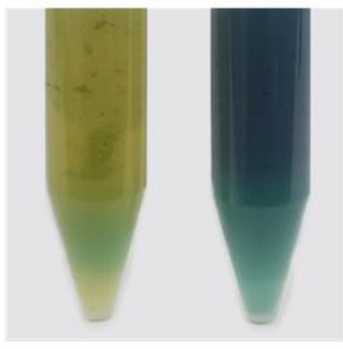

(C)

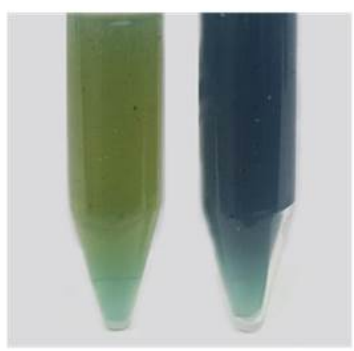

(B)

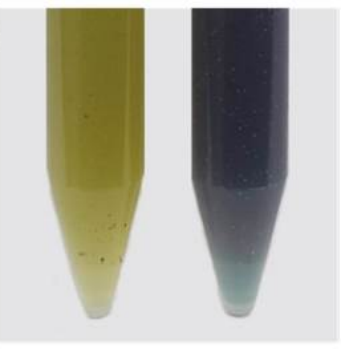

(D)

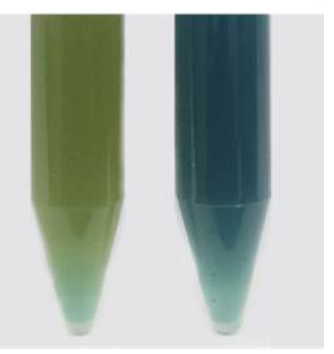

Figure 2. Change in the color in the Snyder test according to the various mouthwashes: (A) CHX; (B) PVI; (C) sodium bicarbonatenormal saline; and $(D)$ distilled water.

Table 1. Evaluation criteria according to the $O G$ and EG values.

\begin{tabular}{ll}
\hline Range & Criteria \\
\hline $0-10$ BBV & I do not detect any smell at all (in the case of intraoral measurement). \\
\hline $10-30$ BBV & I do not detect any smell. \\
\hline $30-50$ BBV & I rarely detect any smell. Normal value of normal person (normal range) \\
\hline
\end{tabular}




\begin{tabular}{ll}
\hline Over 50 BBV & I detect a faint smell. \\
\hline Over 60 BBV & I smell something (I detect the smell when I talk at a close range). \\
\hline Over 80 BBV & I detect a relatively distinct smell (sometimes I feel a distinctive smell). \\
\hline Over 90 BBV & I detect a strong smell (with the same value as that of people with symptoms at the time of getting up). \\
\hline
\end{tabular}

Table 2. Evaluation criteria 24 h after the Snyder test.

\begin{tabular}{|c|c|c|c|c|c|}
\hline Color of the medium after $24 \mathrm{~h}$ & Criteria & Score & Green & Mild & 3 \\
\hline Yellow & High & 1 & Blue & Inactive & 4 \\
\hline
\end{tabular}

Table 3. Mean $\triangle \mathrm{E} \pm S D$ and P-value of the oral environment change by mouthwash.

\begin{tabular}{|c|c|c|c|c|c|c|c|c|c|c|c|c|c|c|c|c|c|c|c|}
\hline \multirow{2}{*}{\multicolumn{2}{|c|}{$\begin{array}{l}\text { Category } \\
\text { Experiment } \\
\text { Method }\end{array}$}} & \multicolumn{5}{|l|}{ CHX } & \multicolumn{4}{|l|}{ PVI } & \multicolumn{2}{|c|}{$\begin{array}{l}\text { Sodium } \\
\text { saline }\end{array}$} & \multicolumn{2}{|c|}{ bicarbonate-normal } & \multicolumn{4}{|c|}{ Distilled water } & \multirow{2}{*}{$\begin{array}{l}\text { ANOV } \\
\text { A } \\
\text { P. } \\
\text { value }\end{array}$} \\
\hline & & $\begin{array}{l}\text { Mean } \Delta \\
\pm \text { SD }\end{array}$ & $\Delta \mathbf{E}$ & $\begin{array}{l}\text { t-test } \\
\text { (P- } \\
\text { value) }\end{array}$ & $\begin{array}{l}\text { Differen } \\
\text { e } M \pm S D\end{array}$ & & $\begin{array}{l}\text { Mean } \\
\underset{\mathrm{SD}}{\Delta \mathrm{E}}\end{array} \pm$ & $\begin{array}{l}\text { t-test } \\
\text { (P- } \\
\text { value) }\end{array}$ & $\begin{array}{l}\text { Differen } \\
\text { e } M \pm S L\end{array}$ & & $\begin{array}{l}\text { Mean } \\
\pm \text { SD }\end{array}$ & $\Delta \mathbf{E}$ & $\begin{array}{l}\text { t-test } \\
\text { (P- } \\
\text { value) }\end{array}$ & $\begin{array}{l}\text { Differenc } \\
\text { e (M } \pm \\
\text { SD) }\end{array}$ & $\begin{array}{l}\text { Mean } \Delta \mathrm{E} \pm \\
\mathrm{SD}\end{array}$ & $\begin{array}{l}\text { t-test (P- } \\
\text { value) }\end{array}$ & $\begin{array}{l}\text { Difference } \\
M \pm S D\end{array}$ & & \\
\hline \multirow[t]{2}{*}{$\mathrm{PH}$} & Before & $\begin{array}{l}7.46 \\
0.26\end{array}$ & \pm & $0.031^{*}$ & $\begin{array}{l}0.22 \\
0.15^{b}\end{array}$ & \pm & $\begin{array}{l}7.30 \pm \\
0.22\end{array}$ & $0.010^{\star}$ & $\begin{array}{l}0.24 \\
0.08^{b}\end{array}$ & \pm & $\begin{array}{l}7.27 \\
0.22\end{array}$ & \pm & 0.206 & $\begin{array}{l}0.18 \quad \pm \\
0.08^{\mathrm{ab}}\end{array}$ & $7.51 \pm 0.33$ & 0.287 & $\begin{array}{l}0.12 \\
0.19^{a}\end{array}$ & \pm & $0.014^{*}$ \\
\hline & After & $\begin{array}{l}7.68 \\
0.25\end{array}$ & \pm & & & & $\begin{array}{l}7.45 \pm \\
0.22\end{array}$ & & & & $\begin{array}{l}7.45 \\
0.14\end{array}$ & \pm & & & $7.38 \pm 0.14$ & & & & \\
\hline $\begin{array}{l}\text { Halitosi } \\
\text { s }\end{array}$ & Before & $\begin{array}{l}47.60 \\
12.16\end{array}$ & \pm & 0.181 & $\begin{array}{l}-8 \\
11.07^{a}\end{array}$ & \pm & $\begin{array}{l}34.20 \\
\pm \\
20.52\end{array}$ & 0.54 & $\begin{array}{l}-6.2 \\
20.71^{a}\end{array}$ & \pm & $\begin{array}{l}11.25 \\
8.66\end{array}$ & \pm & 0.866 & $1 \pm 10.89^{a}$ & $\begin{array}{l}39.25 \\
27.44\end{array}$ & 0.118 & $\begin{array}{l}-17.25 \\
15.84^{a}\end{array}$ & \pm & 0.44 \\
\hline OG & After & $\begin{array}{l}39.6 \\
10.09\end{array}$ & \pm & & & & $\begin{array}{l}28.00 \\
\pm 9.19\end{array}$ & & & & $\begin{array}{l}12.25 \\
7.37\end{array}$ & \pm & & & $\begin{array}{l}22.00 \\
12.08\end{array}$ & & & & \\
\hline $\begin{array}{l}\text { Halitosi } \\
\mathrm{s}\end{array}$ & Before & $\begin{array}{l}38.80 \\
14.75\end{array}$ & \pm & 0.166 & $\begin{array}{l}-12.8 \\
16.92^{a}\end{array}$ & \pm & $\begin{array}{l}36.00 \\
\pm 11.85\end{array}$ & 0.171 & $\begin{array}{l}-4.4 \\
5.90^{\mathrm{a}}\end{array}$ & \pm & $\begin{array}{l}10.00 \\
11.58\end{array}$ & \pm & 0.371 & $\begin{array}{ll}5.5 & \pm \\
10.47^{a} & \end{array}$ & $\begin{array}{l}28.50 \\
22.99\end{array}$ & 0.534 & $2.5 \pm 7.14$ & a & 0.114 \\
\hline EG & After & $\begin{array}{l}26.00 \\
14.80\end{array}$ & \pm & & & & $\begin{array}{l}31.60 \\
\pm 9.53\end{array}$ & & & & $\begin{array}{l}15.50 \\
8.06\end{array}$ & \pm & & & $\begin{array}{l}31.00 \\
29.81\end{array}$ & & & & \\
\hline \multirow[t]{2}{*}{$\begin{array}{l}\text { O'Lear } \\
\text { y index }\end{array}$} & Before & $\begin{array}{l}51.35 \\
15.80\end{array}$ & \pm & $0.001^{* * *}$ & $\begin{array}{l}-22.6 \\
4.98^{b}\end{array}$ & \pm & $\begin{array}{l}58.30 \\
\pm \\
31.02\end{array}$ & $0.022^{*}$ & $\begin{array}{l}-24 \\
14.67^{b}\end{array}$ & \pm & $\begin{array}{l}52.80 \\
19.23\end{array}$ & \pm & $0.001^{* * *}$ & $\begin{array}{l}-29.6 \\
7.84^{b}\end{array}$ & $\begin{array}{l}50.88 \\
25.25\end{array}$ & 0.645 & $\begin{array}{l}-3.13 \\
12.31^{a}\end{array}$ & \pm & $0.012^{*}$ \\
\hline & After & $\begin{array}{l}28.74 \\
13.05\end{array}$ & & & & & $\begin{array}{l}34.30 \\
\pm \\
17.60\end{array}$ & & & & $\begin{array}{l}23.19 \\
12.09\end{array}$ & \pm & & & $\begin{array}{l}47.74 \\
22.0\end{array}$ & & & & \\
\hline \multirow[t]{2}{*}{$\begin{array}{l}\text { S. } \\
\text { mutans }\end{array}$} & Before & $\begin{array}{l}2700 \\
1969.77\end{array}$ & \pm & $0.046^{*}$ & $\begin{array}{l}-1848.33 \\
\pm 711.69\end{array}$ & & $\begin{array}{l}3559 \pm \\
212.13\end{array}$ & $0.027^{*}$ & $\begin{array}{l}-3549 \\
213.55^{c}\end{array}$ & \pm & $\begin{array}{l}1400 \\
180.28\end{array}$ & \pm & 0.075 & $\begin{array}{l}-764.67 \\
386.08^{a b}\end{array}$ & $\begin{array}{l}2210.50 \\
1328.65\end{array} \pm$ & 0.768 & $\begin{array}{l}-110.5 \\
409.41^{a}\end{array}$ & \pm & $0.002^{* *}$ \\
\hline & After & $\begin{array}{l}851.67 \\
147.76\end{array}$ & \pm & & & & $\begin{array}{l}1.00 \pm \\
1.41\end{array}$ & & & & $\begin{array}{l}635.33 \\
489.04\end{array}$ & \pm & & & $\begin{array}{l}2100 \\
919.24\end{array}$ & & & & \\
\hline \multirow[t]{2}{*}{ Snyder } & Before & $\begin{array}{l}2.20 \\
0.45\end{array}$ & \pm & $0.003^{\star \star}$ & $\begin{array}{l}1.6 \\
0.55^{a}\end{array}$ & \pm & $\begin{array}{l}1.80 \pm \\
0.84\end{array}$ & $0.004^{* *}$ & $\begin{array}{l}2.2 \\
0.84^{a}\end{array}$ & \pm & $\begin{array}{l}1.80 \\
0.84\end{array}$ & \pm & $0.003^{* *}$ & $\begin{array}{l}1.6 \\
0.55^{\mathrm{a}}\end{array}$ & $2.25 \pm 0.50$ & $0.015^{*}$ & $\begin{array}{l}1.25 \\
0.50^{\mathrm{a}}\end{array}$ & \pm & 0.188 \\
\hline & After & $\begin{array}{l}3.80 \\
0.45\end{array}$ & \pm & & & & $\begin{array}{l}4.00 \pm \\
0.00\end{array}$ & & & & $\begin{array}{l}4.00 \\
0.00\end{array}$ & \pm & & & $3.50 \pm 0.58$ & & & & \\
\hline
\end{tabular}

${ }^{*}$ The significant difference for the before-after score comparison of the groups by paired t-test $\left(p<0.05 ;{ }^{* *} p<0.01 ;{ }^{* * *} p<0.001\right)$. ${ }^{*}$ The significant difference among the four groups in one-way ANOVA. Different letters $\left(a, b\right.$, and c) by the presented statistically significant result of the post hoc Tukey HSD $\left({ }^{*} p<0.05 ;{ }^{* *} p<0.01 ;{ }^{* * *} p<0.001\right)$.

\section{Discussion}

Ideal mouthwashes should be effective and should rapidly act on more oral bacteria, maintain their activity even at low concentrations, have no side effects, and be usable without discomfort in the mouth [22]. Studies on mouthwashes have been actively conducted to promote a healthy oral environment
[23], and the present study aimed to observe the changes in the oral cavity after the use of various mouthwashes by collecting saliva, and to identify the most appropriate mouthwash.

The saliva plays an important role in confirming healthy oral conditions. The saliva's general functions include lubrication and cleansing, protection of the oral mucosa, antibacterial 
action, remineralization of the teeth, and digestion [24]. It inhibits the development of oral diseases and is necessary to maintain the normal function of the oral tissue [25]. The World Health Organization (WHO) also mentioned the prevention of oral diseases as one of the major challenges that should be overcomes in the future [26]. It is an urgent task to be addressed by managing the dental plaque and changing the saliva composition through oral hygiene management to maintain a healthy oral environment [27]. Therefore, this study was conducted to investigate the changes in the oral environment by applying mouthwashes, which are used more frequently.

As a result, the $\mathrm{pH}$ of saliva was elevated after CHX and PVI gargling, and a significant increase was also shown in the comparison of the groups. Although there was no statistically significant difference after gargling with sodium bicarbonatenormal saline, it was confirmed that sodium bicarbonatenormal saline has the effect of decreasing the $\mathrm{pH}$ because the $\mathrm{pH}$ of saliva was increased after its use. This result was consistent with that of the study of Song and Hur [28], who suggested that gargling is an effective method for the oral cavity as it increases the $\mathrm{pH}$ of saliva in pre-operative patients. There was no statistically significant difference between the OG halitosis and EG halitosis before and after gargling, although there was a decrease with some mouthwashes. Compared to a study that reported that the use of mouthwash is very effective in decreasing halitosis [29], no difference was shown in the present study because the halitosis range of the subjects was normal before gargling. In terms of the O'Leary index, there was a statistically significant decrease in the CHX, PVI, and sodium bicarbonate-normal saline groups before and after the use of all the mouthwashes. The result of the present study was consistent with that of Park's study [30], which reported that the O'Leary index decreased from 49.37 to $32.84 \%$ in the comparison of the oral hygiene status before and after dental hygiene management. Also, in the comparison of all the groups, it was found that all the groups except for the distilled water group (control group) showed a remarkable effect. As a result, the use of mouthwash is considered to cause a change in the oral environment as it removes dental plaque. With regard to the causative organism for dental caries, $S$. mutans, PVI and CHX showed the effect of decreasing the number of bacteria, and especially in the group with PVI gargling, the decrease was more remarkable. It was consistent with the study result that PVI and CHX were found to decrease the CFU of $S$. mutans [31]. This result supports that of another study, that antimicrobial mouthwashes are effective in reducing the CFU of $S$. mutans [32]. Like the result of Goodman's study [33], which reported that sodium bicarbonate-normal saline did not show any effect of inhibiting the growth of microorganisms after gargling, there was also no significant change. As sodium bicarbonate-normal saline's effect of reducing the CFU of $S$. mutans within the oral cavity has not yet been proven, further studies are needed. The results of the Snyder test for caries activity showed that the saliva was inactive to dental caries in all the mouthwashes, which means that physical cleaning with any formulation improves the caries activity in the mouth to some extent. This phenomenon seems to be caused by the mouthwash that cleanses the eliminated matters in the oral cavity and alkalizes the oral cavity.

The $\mathrm{pH}$ in the oral cavity increased after gargling with $\mathrm{CHX}$ and PVI among the various mouthwashes, and the O'Leary index decreased after gargling with $\mathrm{CHX}$, PVI, and sodium bicarbonate-normal saline. The CFU of $S$. mutans decreased with gargling in the order of PVI and CHX. In the Snyder test, all the mouthwashes improved the caries activity compared to before gargling. Based on the present study, PVI caused the most effective change in the oral environment among the various mouthwashes, followed by $\mathrm{CHX}$. It was also confirmed that sodium bicarbonate-normal saline has a potential to maintain a healthy oral cavity and to be used prophylactically.

\section{Conclusion}

In conclusion, mouthwashes should be continuously used. In particular, the use of $7.5 \%$ PVI is recommended to improve the oral environment, such as by reducing the oral bacteria count, followed by $0.2 \% \mathrm{CHX}$. Therefore, a healthy oral environment can be achieved by using an effective and safe mouthwash.

\section{Conflict of Interest}

The authors report no conflict of interest related to this study. The author does not have any financial interest in the companies whose materials are included in the article.

\section{References}

1. Jang YJ, Kim NS. Relationship of oral health behavior to subjective oral health status and the DMFT index in Korean adults. J Korean Soc Dent Hyg 2011; 11: 499-509.

2. Hicks MJ, Uldricks JM, Whitacre HL, Anderson J, Moeschberger ML. A national study of periodontal assessment by dental hygienists. J Dent Hyg 1993; 67: 82-92.

3. Jung GO. A survey about the use of oral hygiene device and awareness especially for the group of people who are aged from 30 to 50 in Daegu and Kyungbuk. J Korean Soc Dent Hyg 2009; 9: 580-592.

4. Lee YH, Jwa SK, Choi MS. A survey on the oral health in accordance with the oral health behavior of children in kindergarten. Korean J Radiol 2013; 7: 419-426.

5. Giertson E, Emberland H, Schieic AA. Effects of mouthrinses with xylitol and fluoride on dental plaque and saliva. Caries Res 1999; 33: 23-31.

6. Lee SR, Kim JH, Huh SY. Comparative study of dental plaque reduction according to various mouthwashes using quantitative light Induced fluorescence-digital. J Dent Hyg Sci 2013; 13: 434-439.

7. Song CE, So HS, Ju D, Kim EJ. Randomized controlled trial for preventing stomatitis and discomfort among acute leukemic patients. J Korean Oncol Nurs 2011; 11: 33-40.

8. Eilers J, Epstein JB. Assessment and measurement of oral mucositis. Semin Oncol Nurs 2004; 20: 22-9. 
9. Mcdowell S. Are we using too much betadine?. RN 1991; 54: 43-45.

10. Brightman LJ, Terezhalmy GT, Greenwell H, Jacobs M, Enlow DH. The effect of a $0.12 \%$ chlorhexidine gluconate mouthrins on orthodontic patients aged 11 through 17 with extablished gingivitis. Am J Orthod 1991; 100: 324-329.

11. Herrera D, Roldan S, Santacruz I, Santos S, Masdevall M, Sanz M. Differences in anti- microbial activity of four commercial $0.12 \%$ chlorhexidine mouthrinse formulations: an in vitro contact test and salivary bacterial count study. J Clin Periodontol 2003; 30: 307-314.

12. Hur MH, Park JH, Lee MY, Youn BH, Ahn HY. The comparative study of a-solution versus tantum or saline in oral care. J People Plants Environ 2007; 10: 35-42.

13. Gershenfeld L. Povidone-iodine as a topical antiseptic. Am J Surg 1957; 94: 938-939.

14. Adamietz IA, Rahn R, Bottcher HD, Schafer V, Reimer K, Fleischer W. Prophylaxis with povidone-iodine against induction of oral mucositis by radiochemotherapy. Support Care Cancer 1998; 6: 373-377.

15. Firouzian A, Khezri HD. A review of the common mouthwashes for oral care utilised by nurses in the critical intubated patients: a literature review of clinical effectiveness. Int J Caring Sci 2014; 7: 711-717.

16. Kim SY, Noh KP, Kim HK, Kim SG, Kook JK, Park SN. Salivary bacterial counts after application of povidoneiodine and chlorhexidine. J Korean Assoc Oral Maxillofac Surg 2009; 35: 312-510.

17. Kim YH, Jun MH, Choi JS. Prevention of chemotherapy induced oral mucositis in patients with acute leukemia by the two oral care protocols. J Korean Acad Adult Nurs 1997; 9: 98-111.

18. Jan MH. Efficacy of bivon saline and chlorhexidine rinses in prevention of oral mucositis in acute leukemia patients during chemotherapy. Korean J Adult Nurs 1998; 10: 111-123.

19. Beck SL, Yasko JM. Guidelines for oral care. Sage Products Crystal Lake IL1993

20. Berry AM, Davidson PM, Masters J, Rolls K. Systematic literature review of oral hygiene practices for intensive care patients receiving mechanical ventilation. Am J Crit Care 2007; 16: 552-562.

21. Kim YH, Jun MH, Choi JS. Prevention of chemotherapy induced oral mucositis in patients with acute leukemia by the two oral care protocols. J Korean Acad Adult Nurs 1997; 9: 98-111.

22. Auh Q, Hong JP, Chun YH. Antibacterial effect on oral normal flora of phytoncide from chamaecyparis obtusa. J Oral Med Pain 2009; 34: 353-362.
23. Ritchey TW, Weaver JM, Sapone M. Oral mouthwash containing zinc and glycine. US.Patent No4 1982; 13: 339-432.

24. Mandel ID. The role of saliva in maintaining oral homeostasis. J Am Dent 1989; 11: 298-304.

25. Jo JW, Sin SC, Seo HS. Tongue plaque removal effect according to tongue cleaner types. J Korean Acad Dent Health 2003; 27: 75-84.

26. Petersen PE. Global policy for improvement of oral health in the 21 st century-implications to oral health research of world health assembly 2007, World Health Organization. Community Dent Oral Epidemiol 2009; 37: 1-8.

27. Aps JKM, Martens LC. The physiology of saliva and transfer of drugs into saliva. Forensic Sci Int 2005; 150: 119-131.

28. Song JA, Hur MH. Effects of a-solution on halitosis and oral status in preoperative npo patients. J Korean Acad Nurs 2012; 42: 405-413.

29. Rosenberg M, Gelernter I, Barki M, Bar-Ness R. Day-long reduction of oral malodor by a two-phase oil: water mouthrinse as compared to chlorhexidine and placebo rinses. J Periodontol 1992; 63: 39-43.

30. Park RJ, Lee YK, Son HK, Hong, MH. Comparison of oral hygiene status by clinical dental hygiene care performance. J Korean Soc Dent Hyg 2014; 14: 5-32.

31. Addy M, Rriffiths C, Isaac R. The effect of povidine iodine on plaque and salivary bacteria: A double-blind crossover trial. J Periodontol 1977; 48: 730-732.

32. Menendez A, Li F, Michalek SM, Kirk K, Makhija SK, Childers NK. Comparative analysis of the antibacterial effects of combined mouth rinses on streptococcus mutans. Oral Microbiol Immunol 2005; 20: 31-34.

33. Goodman, M. Managing the side effects of chemotherapy. Semin Oncol Nurs 1989; 5: 29-52.

\section{*Correspondence to}

Seoul-Hee Nam

Department of Dental Hygiene

College of Health Sciences

Kangwon National University

Republic of Korea 